INDO GLOBAL JOURNAL OF

PHARMACEUTICAL SCIENCES

ISSN 2249- 1023

\title{
Potentializing the Screened Hydrocarbon Degrading Bacterial Community for the Restoration of Hydrocarbon Contaminated Sites
}

\author{
Kanchan Taskar, Sarika Gupta * \\ Department of Bioscience and Biotechnology, Banasthali University, Banasthali, Tonk-304022, Rajasthan, India \\ Address for Correspondance: Sarika Gupta, sarika.ashish@gmail.com
}

\begin{abstract}
Keywords
Hydrocarbon

Degrading

Potential; Bacterial

Community;

Plasmid Profiling;

Land Restoration.
\end{abstract}

\begin{abstract}
The wide spread use of petroleum products leads to contamination of soil and aquatic environment. The discovery of petroleum hydrocarbon brought a lot of relief to the world's energy requirement because of ease of sourcing and conversion. The ease of production, refining and distribution has also brought with it an ever-increasing problem of environmental pollution. One of the ways through which petroleum pollutants can be removed is by solubilization and emulsification. It is the biological factors they affect in our environment and biodegradation of petroleum and individual hydrocarbon they adversely affect the agricultural lands nearby leading to the accumulation of hydrocarbons in the soil followed by barrenness. The soil sample were collected from oil spill sites in Jaipur. These samples were screened for bacterial oil degradation using 1000ppm diesel on Bushnell and Hass salt medium. Hydrocarbon-oxidizing bacteria, fungi and algae are distributed widely in nature. Microbial activities are very important for the renewal of our environment and maintenance of the global carbon cycle. The level of petroleum hydrocarbon degradation was determined in-vitro optimization condition of hydrocarbon degradation by microbes through growth kinetics method at each 4 days interval. The substances that can be degraded or transformed by microorganisms are a huge number of synthetic compounds and other chemicals having ecotoxicological effects like hydrocarbons. So, through the study we are tackling and solving these problems so as to permit the use of microorganisms in bioremediation technologies. Study aims to isolate bacteria capable of degrading hydrocarbon. The soil samples were collected from oil spill sites in Jaipur and study emphasizes to provide a better solution for bioremediation of spilled petroleum hydrocarbons in soil ecosystems. All bacterial isolates able to grow on crude oil were isolated from various hydrocarbon contaminated sites. We isolated Proteus sp., Streptococcus sp., and Enterococcus sp., and tested the synergism. Proteus sp. was found to be the most promising. In vitro optimization studies revealed $\mathrm{pH}$ to be 7.0 and temperature $37^{\circ} \mathrm{C}$ and can degrade hydrocarbon till $1000 \mathrm{ppm}$ concentration by all the isolates. During, plasmid profiling yielding a band of $4.5 \mathrm{~kb}$ common for all indicates it as plasmid responsible for the hydrocarbon degradation. These organisms were studied to determine their biodegrading activities on Hydrocarbon (Diesel) as a sole carbon source using media. Results from this study clearly indicate Proteus sp. can be explored further for mitigation of hydrocarbon to be explored for land reclamation of oil spill site. (C) 2016 iGlobal Research and Publishing Foundation. All rights reserved.
\end{abstract}

Conference Proceedings: International Conference on Advances in Plant and Microbial Biotechnology (PMB2017); JIIT, Noida: February 02-04, 2017

Indo Global Journal of Pharmaceutical Sciences( ISSN 22491023 ; CODEN- IGJPAI; NLM ID: 101610675) indexed and abstracted in EMBASE(Elsevier), SCIRUS(Elsevier),CABI, CAB Abstracts, Chemical Abstract Services(CAS), American Chemical Society(ACS), Index Copernicus, EBSCO, DOAJ, Google Scholar and many more. For further details, visit http://iglobaljournal.com 